\title{
Adoptive transfer of autoimmune splenic dendritic cells to lupus-prone mice triggers a B lymphocyte humoral response
}

\author{
Daniela Sauma $^{1}$ - Natalia Crisóstomo ${ }^{1}$ - Camila Fuentes ${ }^{1} \cdot$ María Alejandra Gleisner $^{1}$. \\ Yessia Hidalgo $^{1}$ - María José Fuenzalida ${ }^{1}$ - Mario Rosemblatt ${ }^{1,2,3}$ • María Rosa Bono ${ }^{1}$
}

Published online: 25 July 2017

(C) The Author(s) 2017. This article is an open access publication

\begin{abstract}
Systemic lupus erythematosus (SLE) is an autoimmune disease characterized by increased autoantibody production that leads to multiple tissue injuries. Dendritic cells (DCs) are important orchestrators of immune responses and key components in fine-tuning the balance between tolerance and immunity. However, their role in autoimmune disorders such as SLE remains uncertain. We analyzed the contribution of DCs in triggering SLE by adoptively transferring splenic DCs from aged autoimmune $[\mathrm{NZB} \times \mathrm{NZW}] \mathrm{F} 1$ (BWF1) mice to young healthy BWF1 mice. We observed that the transfer of DCs from autoimmune mice to pre-autoimmune mice induced high autoantibody titers in the serum of recipient mice. Moreover, autoimmune DCs from aged BWF1 mice were crucial for the expansion and differentiation of plasmablasts and $\mathrm{CD}^{+} \mathrm{B}$ cells or B1-like cells in the peripheral blood, and spleen of recipient BWF1 mice, a phenomenon that is observed in autoimmune BWF1 mice. On the other hand, DCs from aged BWF1 mice participated in the expansion and differentiation of DCs and IFN- $\gamma$-producing T cells. These results reveal that DCs from autoimmune BWF1 mice exhibit
\end{abstract}

Daniela Sauma and Natalia Crisóstomo contributed equally to this work.

Electronic supplementary material The online version of this article (doi:10.1007/s12026-017-8936-9) contains supplementary material, which is available to authorized users.

María Rosa Bono

mrbono@uchile.cl

1 Departamento de Biologia, Facultad de Ciencias, Universidad de Chile, Santiago, Chile

2 Fundación Ciencia \& Vida, Santiago, Chile

3 Facultad de Ciencias Biologicas, Universidad Andres Bello, Santiago, Chile functional and phenotypic characteristics that allow them to trigger B cell hyperactivation, as well as DC and T cell expansion and differentiation, thereby promoting an exacerbated humoral response in lupus-prone mice.

Keywords Dendritic cells $\cdot$ B lymphocytes $\cdot$ Humoral response $\cdot$ Systemic lupus erythematosus $\cdot$ Autoimmunity

$\begin{array}{ll}\text { Abbreviations } \\ \text { SLE } & \text { Systemic lupus erythematosus } \\ \text { NZB } & \text { New Zealand Black } \\ \text { NZW } & \text { New Zealand White } \\ \text { BWF1 } & {[\text { NZB } \times \text { NZW]F1 }} \\ \text { DC } & \text { Dendritic cell } \\ \text { CDC } & \text { Conventional dendritic cell } \\ \text { PDC } & \text { Plasmacytoid dendritic cell }\end{array}$

\section{Introduction}

Dendritic cells (DCs) are crucial in fine-tuning the balance between tolerance and immunity and thus have been implicated in the pathogenesis of various autoimmune diseases, such as systemic lupus erythematosus (SLE). SLE is a chronic autoimmune disease with diverse clinical manifestations. The presence of both autoreactive T and B cells in SLE suggests that this illness could be induced or promoted by functional alterations in the DC populations [1]. Nevertheless, the precise role of DCs in the pathogenesis of SLE remains largely unknown.

The study of DCs in SLE has been challenging, in part due to the discovery of several populations and subsets of DCs with different functions [2]. Previous results have suggested that DCs could have both 
positive and negative regulatory roles in autoimmunity [3-5]. For instance, in vivo ablation or constitutive deletion of DCs in mice with a non-autoimmune background triggers autoimmunity [4]. Similarly, other studies have suggested that DCs could promote central tolerance by transporting peripheral antigens to the thymus [6]. In contrast, other observations support a role for DCs in the induction of autoimmunity. Some groups have reported that DCs play a role in the presentation of self-antigen to autoreactive T cells [4] and the secretion of proinflammatory cytokines in SLE [7, 8]. Aside from priming $\mathrm{T}$ cells, DCs are capable of directly modulating B cell responses, such as B cell growth and differentiation in vitro [9]. It has also been shown that activated DCs from lupus-prone mice are capable to increase directly B cell effector functions, such as antibody production [10]. On the other hand, another study in a murine polygenic model of lupus demonstrated that the constitutive deletion of DCs in MRL.Fas ${ }^{l p r}$ mice decreases the expansion and differentiation of $\mathrm{T}$ cells as well as plasmablast generation [11]. DC functions, distribution, phagocytosis, cytokine secretion, and migration have been found altered in lupus and other autoimmune diseases $[12,13]$, indicating that these cells participate in the maintenance of health.

Several studies have underlined significant DC abnormalities both in humans [14] and in lupus-prone mice [15]. Jin et al. demonstrated that plasmacytoid DCs (pDCs) from SLE patients lacked TLR9 expression, failed in the induction of regulatory $\mathrm{T}$ cell differentiation, and produced high levels of IL-10 [14]. The same phenomenon was reported in $[\mathrm{NZB} \times \mathrm{NZW}] \mathrm{F} 1$ (BWF1) mice, where DCs present an altered phenotype and migratory behavior [15].

We sought to determine the non-redundant functions of pathogenic autoimmune DCs in BWF1 mice, a polygenic and spontaneous autoimmune disease setting. BWF1 mice develop lupus starting at the age of 6 months, characterized by high levels of proteinuria and elevated serum autoantibody titers [16]. By adoptively transferring autoimmune DCs obtained from the spleens of aged autoimmune BWF1 mice into young healthy BWF1 mice, we demonstrated that purified DCs from an autoimmune context were able to trigger humoral autoimmune responses. Moreover, autoimmune DCs from aged BWF1 mice induced the expansion and differentiation of plasmablasts and $\mathrm{CD}^{+} \mathrm{B}$ cells in the peripheral blood of pre-autoimmune mice and participated in the induction of Th1 responses. These results reveal that autoimmune DCs from aged BWF1 mice exhibit functional characteristics that allow them to trigger $\mathrm{B}$ cell hyperactivation and promote an exacerbated humoral response in SLE.

\section{Materials and methods}

\section{Mice and disease evaluation}

Female lupus-prone [NZB $\times$ NZW]F1 (BWF1) mice were purchased from the Jackson Laboratory (Bar Harbor, ME, USA). All mice used in this study were housed in the animal facility of Fundación Ciencia \& Vida. Animal work was carried out under the institutional regulations of the Fundación Ciencia \& Vida and was approved locally by the ethical review committee of the Facultad de Ciencias, Universidad de Chile.

BWF1 female mice aged 2 months old represented young mice, while 8 -month-old mice with severe proteinuria (i.e., $\geq 500 \mathrm{mg} / \mathrm{dl}$ protein) and high antibody titers against doublestranded DNA (dsDNA) represented aged autoimmune mice. Age-matched $[\mathrm{NZW} \times \mathrm{BALB} / \mathrm{c}] \mathrm{F} 1$ female mice were used as controls.

Proteinuria was measured on a monthly basis during the first 6 months of age by a standard semi-quantitative test using a Combur Test N (Roche Diagnostics, Germany). After 6 months of age, proteinuria was measured every week to detect premature lupus. Autoantibodies against dsDNA were measured in serum samples by a standard ELISA using calf thymus DNA. Briefly, $650 \mathrm{ng} / \mathrm{ml}$ dsDNA was used to coat ELISA plates (Nalge Nunc International, USA) in an overnight incubation. Antigen-coated plates were subsequently blocked for $1 \mathrm{~h}$ with phosphate-buffered saline (PBS) containing $1.5 \%$ bovine serum albumin (BSA) and then incubated for $1 \mathrm{~h}$ at room temperature with sample sera (1:250 dilution). The plates were then washed with PBS- $0.05 \%$ Tween 20 and incubated for $1 \mathrm{~h}$ with a peroxidase-labeled goat anti-mouse IgG antibody (Dako, USA). The color was developed by adding the TMB substrate kit (BD Bioscience, USA), and the absorbance at $450 \mathrm{~nm}(\mathrm{OD} 450 \mathrm{~nm})$ was measured using a plate reader (Jenway, UK).

\section{Antibodies}

Monoclonal antibodies (mAbs) against mouse CD86 FITC (GL1), CD138 PE (281-2), CD45R/B220 PE-Cy7 (RA36B2), CD4 PE (RM4-5), CD19 FITC or eFluor 780 (6D5), IL-10 PE (JES5-16E3), CD1d APC (1B1), CD69 (H1.2F3), IgM PE-Cy7 (RMM-1), purified CD16/32 (93), NK1.1 Alexa Fluor 488 (PK136), CD49b PE (DX5), CD11b APC (N1/70), and PDCA-1 APC (927) were purchased from BioLegend (San Diego, CA, USA). mAbs against mouse CD5 PE-Cy7 (53-7.3), CD11c PE (N418), IFN- $\gamma$ FITC (XMG1.2), CD62L PE (MEL-14), CD25 APC (PC61.5), CD273 PE (PD-L2) (TY25), CD3 FITC (17A2), purified CD3 (145-2C11), and CD279 FITC (PD-1) (J43) were purchased from eBioscience (San Diego, CA, USA). mAbs against mouse IgD FITC (11-26c.2a), I-Ad FITC or APC (MHC-II) (AMS32.1), CD79b FITC (HM79-12), and mouse anti-Armenian 
hamster IgG2/3 FITC (G70-204) were purchased from BD Pharmingen (San Diego, CA, USA). Peroxidase-labeled goat anti-mouse IgG antibody was purchased from Dako (USA).

\section{Flow cytometry}

Surface staining was performed in ice-cold PBS with $2 \%$ fetal calf serum (FCS) for $30 \mathrm{~min}$ in the presence of Fc $\gamma \mathrm{R}$ blocking antibody (CD16/32). $1.5 \mathrm{ng} / \mu$ l propidium iodide (PI) (SigmaAldrich) was used for live-dead cell discrimination.

Intracellular staining was performed with the BD Cytofix/ Cytoperm and Perm/Wash buffers. For intracellular IFN- $\gamma$ staining, $1 \times 10^{6}$ cells were cultured for $4 \mathrm{~h}$ at $37^{\circ} \mathrm{C}$ in RPMI 1640 medium with $10 \%$ FCS containing $1 \mu \mathrm{g} / \mathrm{ml}$ ionomycin, $0.25 \mu \mathrm{M}$ phorbol myristate acetate (PMA), and $10 \mu \mathrm{g} / \mathrm{ml}$ brefeldin A. For intracellular IL-10 staining, $1 \times 10^{6}$ cells were cultured for $5 \mathrm{~h}$ at $37^{\circ} \mathrm{C}$ in RPMI 1640 medium with $10 \%$ FCS containing $2 \mu \mathrm{g} / \mathrm{ml}$ lipopolysaccharide (LPS) (Sigma), $1 \mu \mathrm{g} / \mathrm{ml}$ ionomycin (Sigma), PMA (Sigma), and $10 \mu \mathrm{g} / \mathrm{ml}$ GolgiStop (BD Biosciences, USA). Viability dye eFluor 780 reagent (eBioscience) was used for live-dead cell discrimination.

Flow cytometry was conducted on a FACSCanto II flow cytometer (BD Biosciences), and data analysis was performed using the FlowJo software (Tree Star, Inc., Ashland, OR, USA).

\section{Isolation of splenic DCs}

Spleens of aged BWF1 and control $[\mathrm{NZW} \times \mathrm{BALB} / \mathrm{c}] \mathrm{F} 1$ mice were mechanically disaggregated. The cells were incubated for $45 \mathrm{~min}$ at $37{ }^{\circ} \mathrm{C}$ in a solution containing $1 \mathrm{mg} / \mathrm{ml}$ collagenase D (Roche) and $20 \mathrm{U} / \mathrm{ml}$ DNase I (Roche) dissolved in PBS supplemented with 2\% FCS. Single cell suspensions were washed in RPMI 1640 medium and depleted of erythrocytes by incubation for 5 min with red blood cell (RBC) lysis buffer (BioLegend, USA) at $4{ }^{\circ} \mathrm{C}$. Total $\mathrm{CD} 11 \mathrm{c}^{+}$cells were purified by cell sorting on a FACSAria II (BD Biosciences). Before cell sorting, $\mathrm{T}$ and $\mathrm{B}$ cells were eliminated by labeling the cells with a mixture of rat anti-mouse CD3 FITC plus Armenian hamster antimouse CD79b FITC. Then, cells were incubated with mouse anti-Armenian hamster IgG2/3 FITC, followed by incubation with Dynabeads coupled with anti-rat IgG and anti-mouse IgG (Invitrogen). Enriched cells were further stained with anti-CD3 and anti-CD79b antibodies to eliminate residual $\mathrm{T}$ or $\mathrm{B}$ cells and with an anti-CD $11 \mathrm{c}$ antibody to select pure $\mathrm{CD} 11 \mathrm{c}^{+}$cells by cell sorting. The purity of cells was $>98 \%$, as determined by flow cytometry.

\section{Adoptive transfer of DCs}

Two doses of $4 \times 10^{6}$ splenic DCs from aged BWF1 (autoimmune DCs, $\mathrm{H}-2^{\mathrm{dxz}}$ haplotype) or $[\mathrm{NZW} \times \mathrm{BALB} / \mathrm{c}] \mathrm{F} 1$ (control DCs, $\mathrm{H}-2^{\mathrm{zxd}}$ haplotype) mice were injected intravenously (i.v.) into young healthy BWF1 mice or $[\mathrm{NZW} \times \mathrm{BALB} / \mathrm{c}] \mathrm{F} 1$ control mice within an interval of 20 days apart. Every 5 days, the mice were tested for proteinuria, and blood samples were taken to measure the anti-dsDNA autoantibody titers in the serum by ELISA. Flow cytometric analysis of the blood samples was conducted every 15 days to evaluate $\mathrm{T}$ and $\mathrm{B}$ cell phenotypes. Finally, at the end of 2 months, the mice were sacrificed, and DCs and T and B cells from the lymphoid organs were harvested and analyzed by flow cytometry. To determine which population of DCs is responsible for the induction of autoantibodies in young healthy BWF1 mice, we injected purified $0.6 \times 10^{6}$ autoimmune splenic conventional or plasmacytoid DCs (cDCs or pDCs, respectively) in a single dose into young BWF1 mice and blood samples were taken to measure anti-dsDNA autoantibody titers in the serum by ELISA.

\section{Serum cytokine detection}

The cytokine levels were measured from the serum of mice using the cytometric bead array (CBA) assay. To detect inflammatory and $\mathrm{T}$ helper cell cytokines, we used the BD CBA Mouse Inflammation Kit and the CBA Mouse Th1/ Th2/Th17 Kit according to the manufacturer's instructions (BD Biosciences, USA).

\section{DC co-culture with $B$ and T cells}

Total splenic B cells from young BWF1 mice were isolated by negative selection using the $\mathrm{B}$ cell isolation kit from Miltenyi (Miltenyi Biotec, USA) following the manufacturer's instructions. The B cell purity was always $\geq 95 \%$, as determined by flow cytometry. Splenic $\mathrm{CD} 4^{+} \mathrm{CD} 25^{-} \mathrm{T}$ cells from young BWF1 mice were sorted on a FACSAria II sorter (BD Biosciences). The purity of the cells was always $\geq 90 \%$, as monitored by flow cytometry. Total splenic $\mathrm{CD} 11 \mathrm{c}^{+}$cells from aged BWF1 or control mice were sorted on a FACSAria II sorter (BD Biosciences) as described in section "Isolation of splenic DCs." The purity of the DCs was $>98 \%$, as determined by flow cytometry.

DCs from aged BWF1 or control mice were co-cultured with young BWF1 B cells at a 1:5 ratio in 96-well U-bottomed plates in RPMI 1640 medium supplemented with $10 \%$ FCS and $0.5 \mu \mathrm{g} / \mathrm{ml} \beta$-mercaptoethanol (Gibco, Life Technologies). The cells were cultured at $37{ }^{\circ} \mathrm{C}$ in a humidified $5 \% \mathrm{CO}_{2}$ incubator for $24 \mathrm{~h}$ or 3 days before flow cytometric analysis. Alternatively, DCs from aged BWF1 or control mice were cocultured with T cells from a young BWF1 mice at a 1:2 ratio in 
96-well U-bottomed plates in IMDM medium supplemented with $10 \%$ FCS, $0.5 \mu \mathrm{g} / \mathrm{ml}$ amphotericin B (Fungizone) (Gibco, Life Technologies), $0.5 \mu \mathrm{g} / \mathrm{ml} \beta$-mercaptoethanol, and $50 \mu \mathrm{g} / \mathrm{ml}$ gentamicin (Gibco, Life Technologies) in the presence of $1 \mu \mathrm{g} / \mathrm{ml}$ of purified soluble anti-CD3 antibody (clone $2 \mathrm{C} 11$ ). The cells were cultured at $37^{\circ} \mathrm{C}$ in a humidified $5 \% \mathrm{CO}_{2}$ incubator for 5 days to achieve $\mathrm{T}$ cell differentiation before flow cytometric analysis.

\section{Statistical analysis}

Statistical analysis was performed with the GraphPad Prism program, version 4 (GraphPad Software, San Diego, CA, USA). The data were compared using a one-way ANOVA after verification of normal distribution. Bonferroni's tests were used when multiple comparisons were performed in the same experiment. When normal distribution was not verified, the data were analyzed with Kruskal-Wallis and Dunn's post tests. For the comparison of the data between control DCtreated mice and autoimmune DC-treated mice, a nonparametric two-tailed Mann-Whitney test was performed. $p$ values $<0.05$ were considered significant.

\section{Results}

\section{DCs from aged autoimmune BWF1 mice exacerbate autoantibody secretion in young healthy BWF1 mice}

In light of published results $[15,17]$ demonstrating the abnormal function and phenotype of DCs in aged autoimmune BWF1 mice, we sought to determine the role of DCs in the development of lupus in the BWF1 murine model in vivo. For this, we adoptively transferred total splenic DCs (consisting of cDCs and pDCs) obtained from aged autoimmune BWF1 or control $[\mathrm{NZW} \times \mathrm{BALB} / \mathrm{c}] \mathrm{F} 1$ mice to young healthy BWF1 or control $[\mathrm{NZW} \times \mathrm{BALB} / \mathrm{c}] \mathrm{F} 1 \mathrm{mice}$. The phenotype of transferred cells is shown in Suppl. Fig. 1a and b. When sorting spleen cells based on CD11c expression, the resulting population (over $98 \%$ of $\mathrm{CD}_{11 \mathrm{c}^{+}}$cells) contained a fraction of natural killer (NK) CD11 c-expressing cells $\left(\mathrm{CD} 11 \mathrm{c}^{+} \mathrm{NK} 1.1^{+}\right)$. On the other hand, the $\mathrm{CD} 11 \mathrm{c}^{+} \mathrm{NK} 1.1^{-}$ fraction contained pDCs $\left(\mathrm{CD} 11 \mathrm{c}^{\text {int }} \mathrm{B} 220^{+}\right)$and $\mathrm{cDCs}$ $\left(\mathrm{CD} 11 \mathrm{c}^{\mathrm{hi}} \mathrm{B} 220^{-}\right)$in similar percentages when comparing control and autoimmune cells. Thus, transferred cells consisted of a known mixture of pDCs and cDCs. To assess the effect of adoptively transferred DCs on young healthy BWF1 mice, we evaluated the production of $\operatorname{IgG}$ autoantibodies against dsDNA in serum samples of these mice. Following the transfer of aged autoimmune BWF1 DCs at days 0 and 20, we observed high autoantibody production compared to the production induced by the transfer of control DCs (Fig. 1a). The maximum effect was observed 10 days after the second

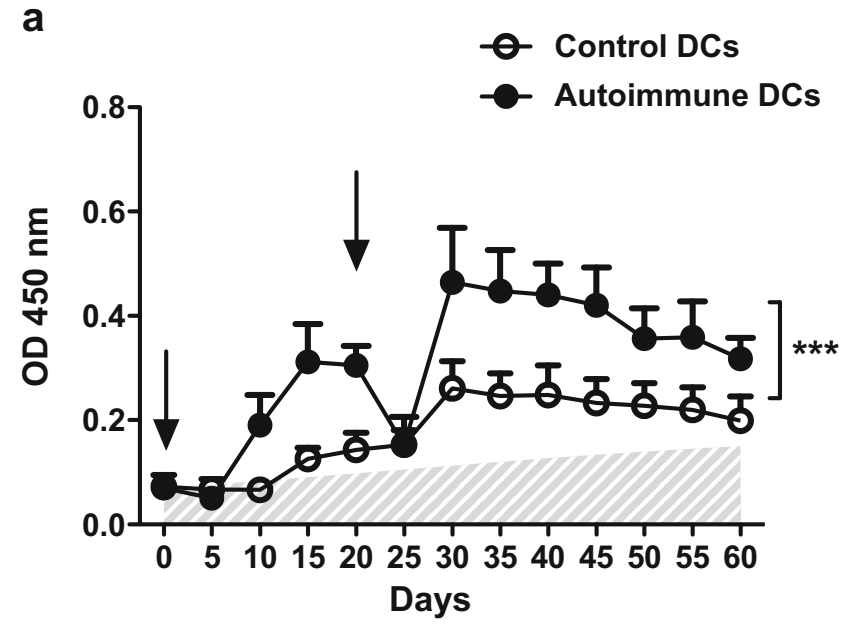

b
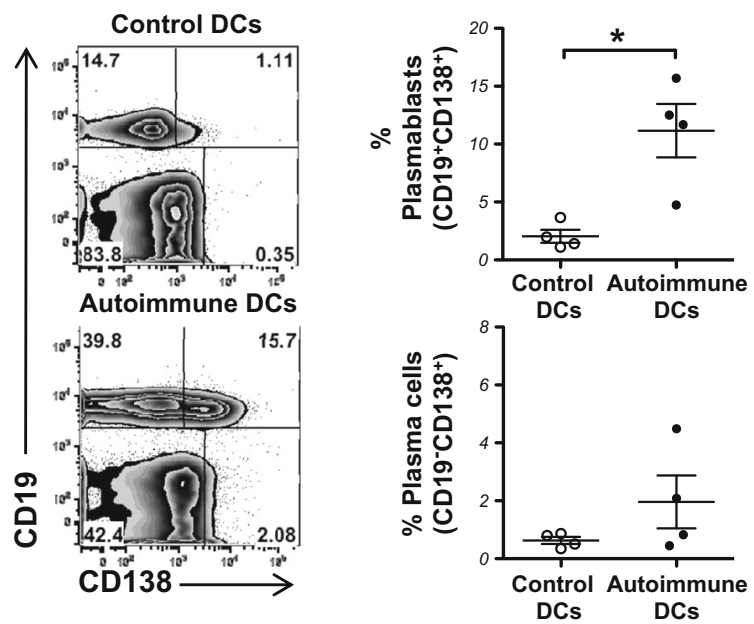

Fig. 1 Induction of anti-dsDNA autoantibodies by transfer of autoimmune dendritic cells $(D C s)$ to lupus-prone young BWF1 mice. a Splenic DCs from aged $[\mathrm{NZW} \times \mathrm{BALB} / \mathrm{c}] \mathrm{F} 1$ control (control DCs) or aged BWF1 mice (autoimmune DCs) were sorted and injected i.v. $\left(4 \times 10^{6} / \mathrm{mouse}\right)$ into young BWF1 mice at days 0 and 20 (black arrows). Serum was obtained every 5 days after the first injection over the course of 2 months and tested for anti-dsDNA autoantibodies by standard ELISA. White circles sera from young BWF1 mice treated with control DCs; black circles sera from young BWF1 mice treated with autoimmune DCs; shaded area sera from young untreated BWF1 mice. The data are presented as the mean \pm S.E.M. $(n=4$ mice per group); $* * * p<0.001$ (two-way ANOVA). b Representative FACS analysis in the blood of young BWF1 mice injected with control or autoimmune DCs to identify $\mathrm{CD} 19^{+} \mathrm{CD} 138^{+}$plasmablast cells and CD $19^{-}$CD $138^{+}$plasma cells among lymphoid cells 60 days post injection (numbers represent the percentage of events in each quadrant). The graphs on the right show the percentage of plasmablasts and plasma cells in the blood of BWF1 mice treated with control or autoimmune DCs. The data in the graphs are presented as the mean \pm S.E.M. ( $n=4$ mice per group); $* p<0.05$ (two-tailed Mann-Whitney test)

administration of DCs, showing that DCs from autoimmune BWF1 mice induce autoantibody secretion in young BWF1 mice a short period after adoptive transfer (Fig. 1a). Interestingly, the transfer of autoimmune DCs to control mice did not induce autoantibody production (Suppl. Fig. 2a), 
indicating that the genetic background is important for activating autoreactive B cells. Moreover, both $\mathrm{pDCs}$ and $\mathrm{cDCs}$ from autoimmune mice are sufficient to trigger the production of autoantibodies since the transfer of $0.6 \times 10^{6} \mathrm{pDCs}$ or cDCs to young healthy BWF1 mice induced autoantibody production (Suppl. Fig. 2b). Autoantibody production was not followed by renal damage, as proteinuria levels did not increase in either group of treated mice (data not shown).

In agreement with the autoantibody production, the percentage of $\mathrm{CD} 19^{+} \mathrm{CD} 138^{+}$plasmablasts and $\mathrm{CD} 19^{-} \mathrm{CD} 138^{+}$ plasma cells increased in the peripheral blood of young, healthy BWF1 mice injected with autoimmune DCs (Fig. 1b). Together, these findings demonstrate that autoimmune DCs substantially promote the generation of autoantibodies, thereby triggering autoimmunity in young, previously healthy BWF1 mice.

\section{Long-lived memory B cells are expanded in young,} healthy BWF1 mice treated with autoimmune DCs

To understand how autoimmune DCs drive humoral autoimmunity, we analyzed the percentage of naïve and long-lived memory B cells, defined as $\operatorname{IgM}^{+} \operatorname{IgD}^{-}$cells by Pape and collaborators [18], in the spleens of mice sacrificed 60 days post injection of control or autoimmune DCs. As shown in Fig. 2a, the transfer of autoimmune DCs significantly reduces the percentage of $\operatorname{IgM}^{+} \operatorname{IgD}^{+}$naïve B cells and increases the percentage of $\operatorname{IgM}^{+} \operatorname{IgD}^{-}$long-lived memory $\mathrm{B}$ cells in the spleens of the recipient mice. Although not statistically significant, the absolute number of naïve or long-lived memory $B$ cells follows the same trend (Suppl. Fig. 3a and b, respectively). Similar to what we found in the blood, the absolute cell numbers of both $\mathrm{CD} 138^{+} \mathrm{CD} 19^{+}$

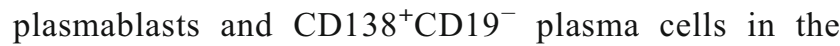
spleen increase following transfer of autoimmune DCs (Suppl. Fig. 4). In concordance with the loss of naïve B cells, the total B cells from the autoimmune DC-treated mice presented a higher activation state, as demonstrated by an increase in the expression of the activation markers CD86 and PD-L2 and a lower MHC-II expression, compared to control mice (Fig. 2b). Overall, these results indicate that autoimmune DCs alone are capable of triggering B cell differentiation into memory B cells in young, healthy BWF1 mice.

a
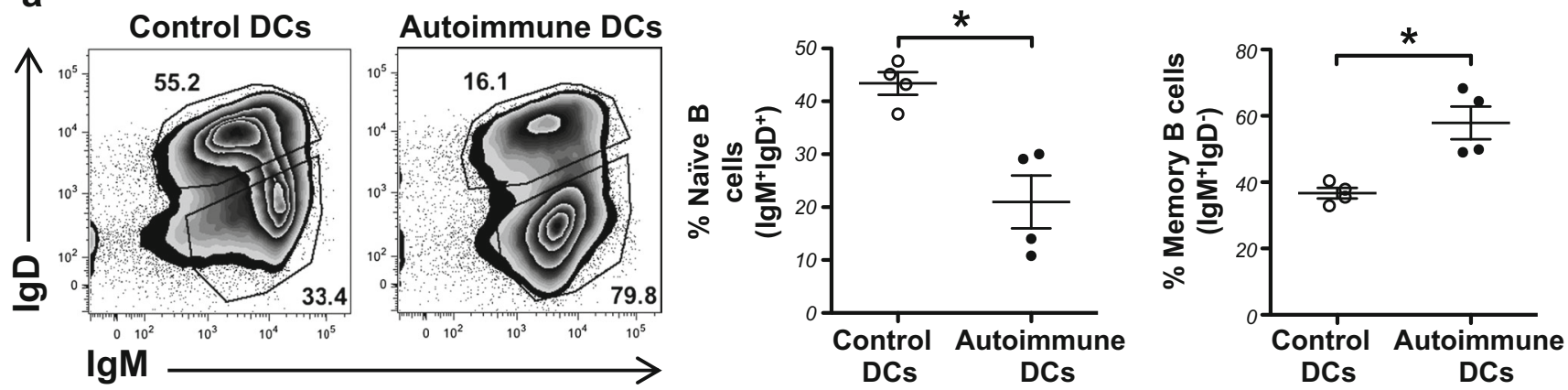

b

CD86

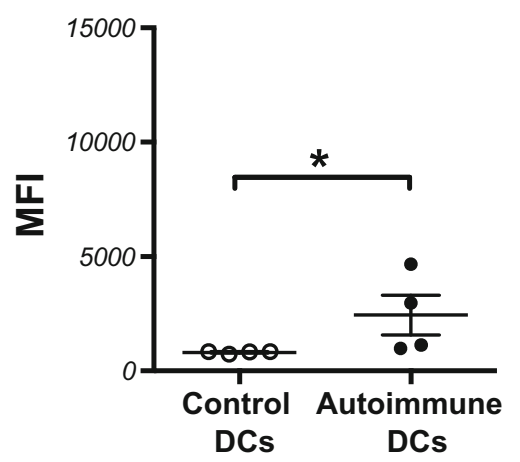

Fig. 2 Autoimmune DCs are critical for B cell maturation and activation. a Representative FACS analysis of splenic $\operatorname{IgM}^{+} \operatorname{IgD}{ }^{+}$naïve and $\mathrm{IgM}^{+} \mathrm{IgD}^{-}$memory B cells, among total B cells, of young BWF1 mice 60 days post injection of control or autoimmune DCs (numbers represent the percentage of events in each gate). The graphs on the right show the percentage of naïve and memory B cells in the spleens of BWF1 mice
PD-L2

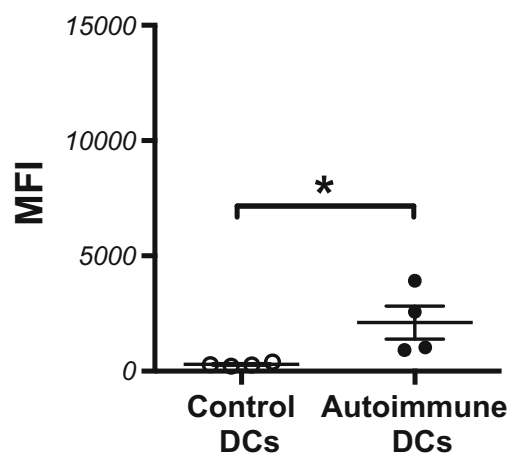

MHC-II

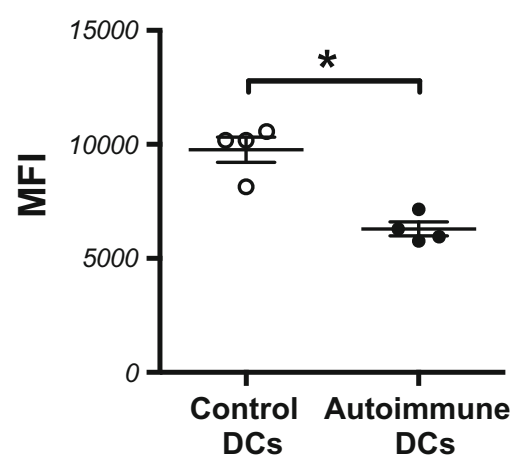

treated with control or autoimmune DCs. b Mean fluorescence intensity (MFI) of CD86, PD-L2, and MHC-II staining within splenic $\mathrm{CD} 19^{+} \mathrm{CD} 11 \mathrm{c}^{-}$cells (total B cells) from young BWF1 mice treated with control or autoimmune DCs. The data in the graphs are presented as the mean \pm S.E.M. ( $n=4$ mice per group); $* p<0.05$ (two-tailed MannWhitney test) 
Fig. $3 \mathrm{CD}^{+} \mathrm{B}$ cells are highly expanded in the blood and spleen of young BWF1 mice injected with autoimmune DCs. a Percentage of $\mathrm{CD}^{+} \mathrm{B} 220^{+} \mathrm{B}$ cells among lymphoid cells in the blood of BWF1 mice at $0,15,30$, 45 , and 60 days post injection with control or autoimmune DCs. b Percentage of

$\mathrm{CD} 19^{+} \mathrm{CD} 11 \mathrm{c}^{-} \mathrm{CD}^{+} \mathrm{B}$ cells in the peripheral blood and spleens of BWF1 mice treated with control or autoimmune DCs 60 days after cell transfer. The data in the graphs are presented as the mean \pm S.E.M. $(n=4$ mice per group); $* p<0.05 ; * * p<0.01$; $* * * p<0.001$ (two-tailed Mann-Whitney test)
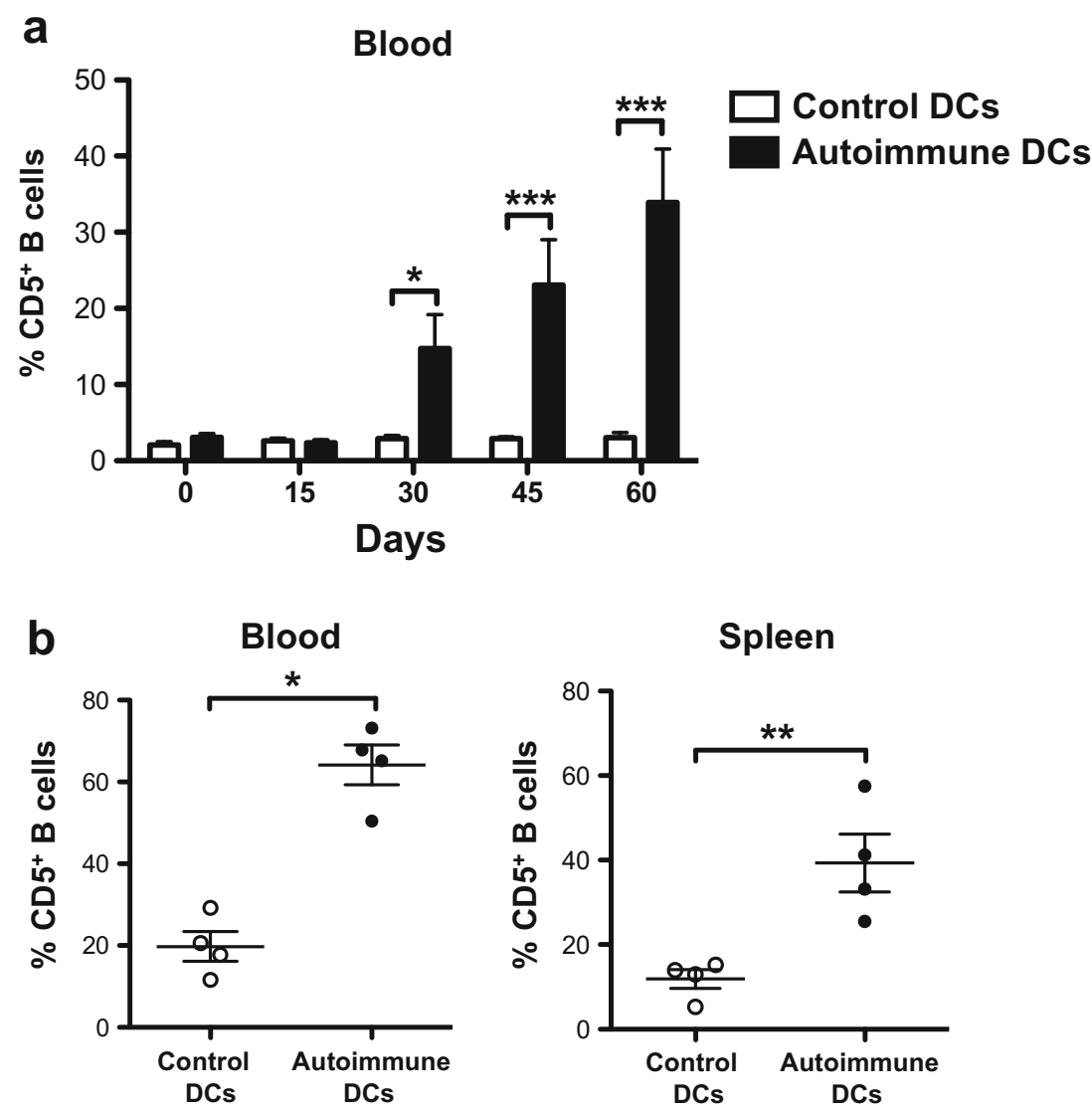

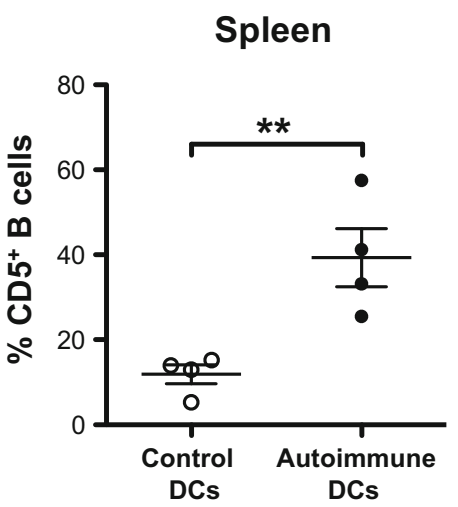

\section{$\mathrm{CD5}^{+} \mathrm{B}$ cells are expanded in young, healthy BWF1 mice treated with autoimmune DCs}

Although short-lived plasmablasts are a primary source of autoantibodies in various lupus mouse models, $\mathrm{CD}^{+} \mathrm{B}$ cells or B1-like cells have also been characterized as possible producers of autoantibodies $[17,19,20]$. $\mathrm{CD}^{+} \mathrm{B}$ cells are known for their capacity to produce polyreactive natural antibodies, which recognize autoantigens with low affinity. $\mathrm{CD} 5^{+} \mathrm{B}$ cells, which are found preferentially in the peritoneal cavity, are increased in the peripheral blood of SLE patients, and they are positively correlated with some autoantibodies detected in the serum [21]. To investigate whether autoimmune DCs promote the expansion of $\mathrm{CD}^{+} \mathrm{B}$ cells, we analyzed the presence of $\mathrm{CD}^{+} \mathrm{B}$ cells in the blood and spleens of BWF1 mice treated with control or autoimmune DCs and found that the frequency of CD5+ B cells in the blood increase 30 days after the transfer of autoimmune DCs (Fig. 3a). We also observed an increase in the percentage of $\mathrm{CD}^{+} \mathrm{B}$ cells in the spleens 60 days post transfer of autoimmune DCs compared to the transfer of control DCs (Fig. 3b). Besides, transfer of autoimmune DCs had a major effect on the expansion of $\mathrm{CD}^{+} \mathrm{B}$ cells, even higher to the one observed in aged BWF1 mice with lupus (Suppl. Fig. 5).

Patients with SLE have higher levels of serum IL-10 than healthy subjects [22]. Increased IL-10 may be attributed to the expansion of monocytes, B10 cells, and regulatory B cells and possibly to a subpopulation of memory $\mathrm{T}$ lymphocytes [23, 24]. To study whether the transfer of autoimmune DCs promotes the expansion of B10 cells, we evaluated IL-10 production using intracellular staining of splenic B cells from young BWF1 mice sacrificed 60 days post injection of control or autoimmune DCs. As shown in Suppl. Fig. 6a, the administration of autoimmune DCs had a potent effect on the expansion of splenic B10 cells compared to control DCs. Also, regulatory $\mathrm{B}$ cells, identified as $\mathrm{CD} 1 \mathrm{~d}^{\mathrm{hi}} \mathrm{CD}^{+}$, were increased in autoimmune DC-treated mice (Suppl. Fig. 6b). Collectively, these findings demonstrate that adoptively transferred autoimmune DCs are involved in the expansion of $\mathrm{CD}^{+} \mathrm{B}$ cells and regulatory B cells in young, healthy BWF1 mice.

\section{Autoimmune DCs expand cDCs and pDCs}

It has been reported that in aged autoimmune BWF1 mice, DCs accumulate in lymphoid organs, such as the spleen, mesenteric lymph nodes, and peripheral lymph nodes [15]. Interestingly, the adoptive transfer of autoimmune DCs to young healthy BWF1 mice generated a significant expansion of DCs in the blood and spleen (Fig. 4). Adoptive transfer of autoimmune DCs in young BWF1 mice mainly expanded cDCs in the blood while in the spleen, we observed an 

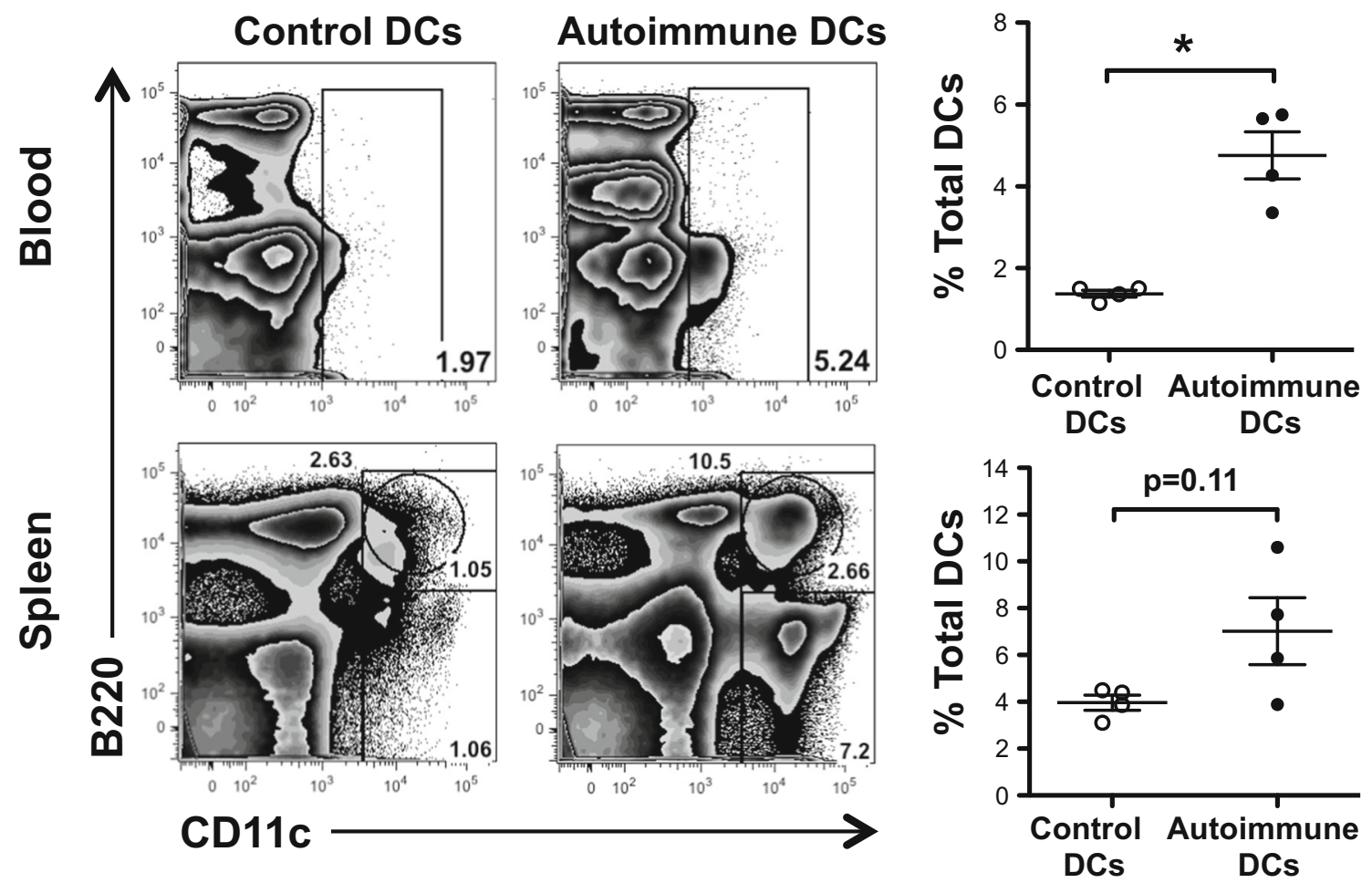

Fig. 4 cDCs and pDCs expand in the blood and spleen of young BWF1 mice injected with autoimmune DCs. Representative FACS analysis of endogenous DCs among lymphoid cells, comprising CD11 $\mathrm{c}^{\mathrm{hi}} \mathrm{B} 220^{-} \mathrm{cDC}$ and $\mathrm{CD} 11 \mathrm{c}^{\text {int }} \mathrm{B} 220^{+} \mathrm{pDC}$ subsets, in the peripheral blood and spleen of BWF1 mice 60 days post injection with control or autoimmune DCs

increase in both cDCs and pDCs. The expansion of DCs in the peripheral blood was observed starting on day 30 after the first injection, and the percentage of these cells doubled by the time the mice were sacrificed. Moreover, in Fig. 4, we can observe directly on the contour graphs that autoimmune DC-treated mice produce a larger subpopulation of cells that are negative for CD11c and express an intermediate level of B220 that correspond to $\mathrm{CD}^{+} \mathrm{B}$ cells present in the blood and spleen.

\section{Autoimmune DCs are crucial for the differentiation of $\mathrm{CD}^{+}{ }^{+} \mathrm{T}$ cells into IFN- $\gamma$-producing cells}

Next, we investigated the role of autoimmune DCs on the T cell response. BWF1 mice develop pathological proteinuria levels starting at 6 to 7 months of age, severe involution of the thymus and splenomegaly involving T cells, B cells, and DCs $[25,26]$. We studied these characteristic phenomena of lupus in young, healthy BWF1 mice treated with control or autoimmune DCs. Involution of the thymus was not observed in autoimmune DC-treated mice, indicating that this may be a late symptom of lupus (Fig. 5a). On the other hand, mice treated with autoimmune DCs showed modest splenomegaly, as evaluated by the absolute cell count of total splenocytes (Fig. 5a). Although we found higher absolute $\mathrm{CD} 4^{+} \mathrm{T}$ cell numbers in the spleens of mice treated with autoimmune DCs than in those of control DC-treated mice (Fig. 5b), no (numbers represent the percentage of cells in each gate). The graphs on the right show the percentage of total DCs in the blood and spleen of BWF1 mice treated with control or autoimmune DCs. The data in the graphs are presented as the mean \pm S.E.M. ( $n=4$ mice per group); ${ }^{*} p<0.05$ (two-tailed Mann-Whitney test)

differences were observed on the activation status of these cells, as assessed by CD25, CD62L, CD69, and PD-1 expression (Fig. 5c). Because peripheral blood mononuclear cells (PBMCs) from SLE patients produce large amounts of IFN- $\gamma[22,27]$, we evaluated whether autoimmune DCs could be involved in Th1 cell differentiation. Consistent with this, the frequency of IFN- $\gamma$-producing cells among $\mathrm{CD}^{+}{ }^{+} \mathrm{T}$ cells derived from BWF1 mice treated with autoimmune DCs was higher than that in control DC-treated mice (Fig. 5d). Next, we analyzed serum obtained from the mice 60 days after the transfer of DCs. In agreement with the induction of IFN- $\gamma$ producing $\mathrm{T}$ cells, we observed that autoimmune $\mathrm{DC}$ transfer to young BWF1 mice induced a striking increase in IL-12, IL6, and IL-10 compared to mice injected with control DCs (Fig. 5e). Thus, it can be concluded that autoimmune DCs contribute to the hyperproduction of IFN- $\gamma$ by $\mathrm{T}$ cells and to the induction of a potent inflammatory cytokine production in diseased BWF1 mice.

\section{Autoimmune DCs drive B cell maturation and T cell differentiation in vitro}

To determine whether B cell activation and differentiation following the transfer of autoimmune DCs was due to direct interactions between DCs and B cells, we carried out in vitro experiments with purified subpopulations. For this, we co- 


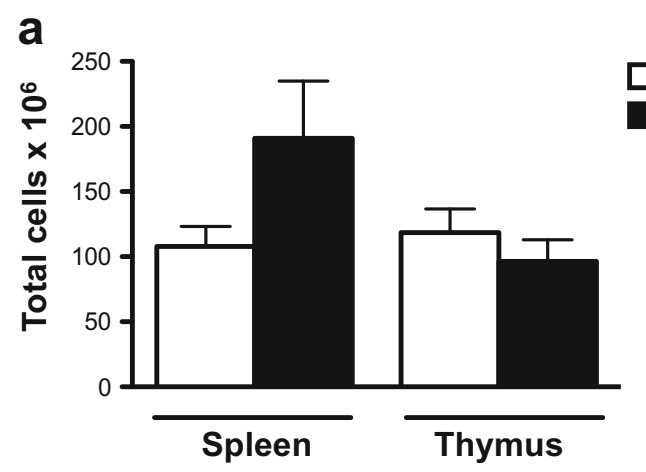

Control DCs

Autoimmune DCs

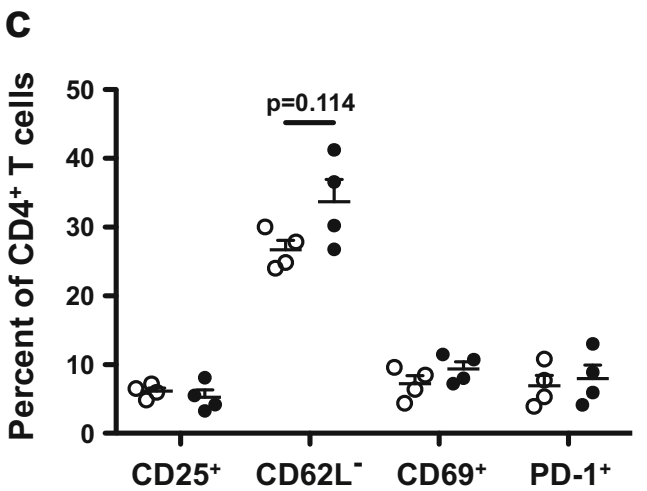

- Control DCs

- Autoimmune DCs

e

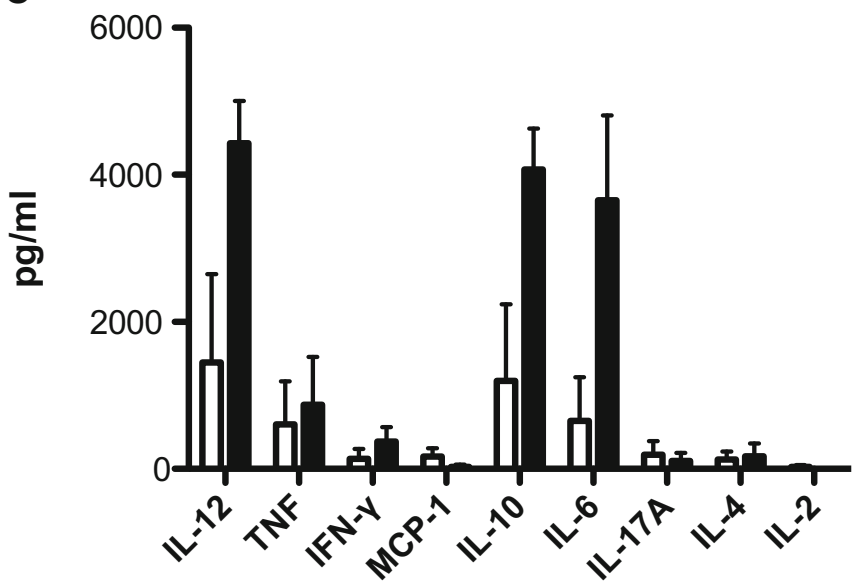

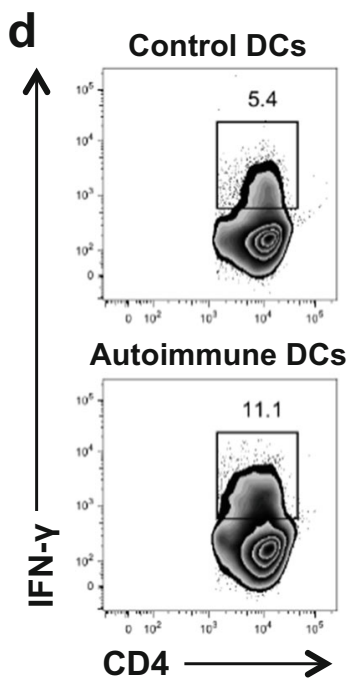

b

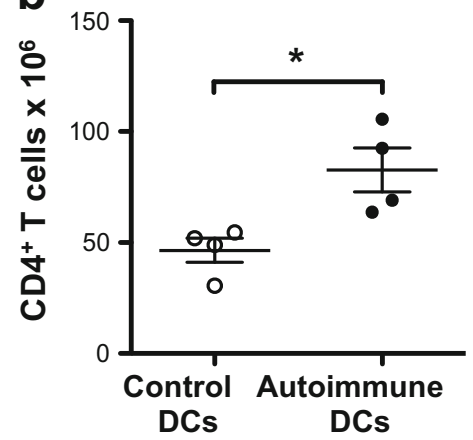

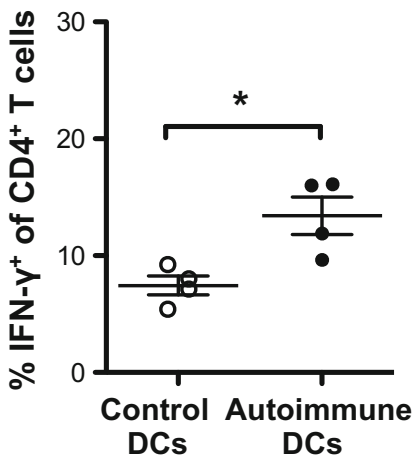

\section{Serum cytokines}

Fig. 5 Autoimmune DCs induce the expansion, but not activation, of T cells and drive differentiation of T $\mathrm{CD} 4^{+}$cells into IFN- $\gamma$-producing cells. a Total cell count in spleens and thymi of BWF1 mice 60 days post injection with control (white bars) or autoimmune (black bars) DCs. b Cell numbers of total $\mathrm{CD}^{+} \mathrm{CD}^{+}$splenic T cells from BWF1 mice 60 days post injection with control (white dots) or autoimmune (black dots) DCs. c Percentage of splenic $\mathrm{CD}^{+} \mathrm{T}$ cells among lymphoid cells expressing various activation markers in BWF1 mice 60 days post injection with control (white dots) or autoimmune (black dots) DCs. d Representative FACS analysis of intracellular IFN- $\gamma$ staining of PMA/ ionomycin/brefeldin A-stimulated splenocytes from BWF1 mice 60 days post injection with control (white dots) or autoimmune (black dots) DCs (numbers represent the percentage of cells in each gate). The graph on the right shows the percentage of IFN $-\gamma^{+}$cells within a $\mathrm{CD} 4^{+}$gate. The data in the graphs are presented as the mean \pm S.E.M. ( $n=4$ mice per group); $* p<0.05$ (two-tailed Mann-Whitney test). e CBA analysis of serum cytokines. Cytokines were tested in the serum of BWF1 mice obtained 60 days after the transfer of autoimmune (black bars) or control (white bars) DCs. The data in the bar graphs are presented as the mean \pm S.E.M. 


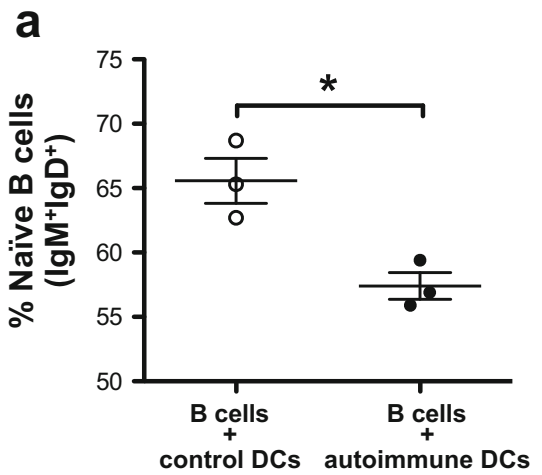

CD86

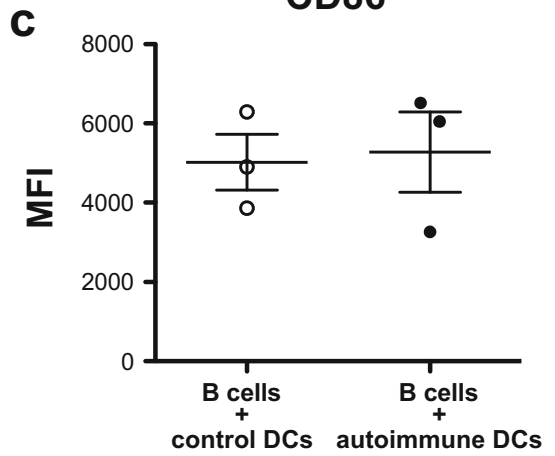

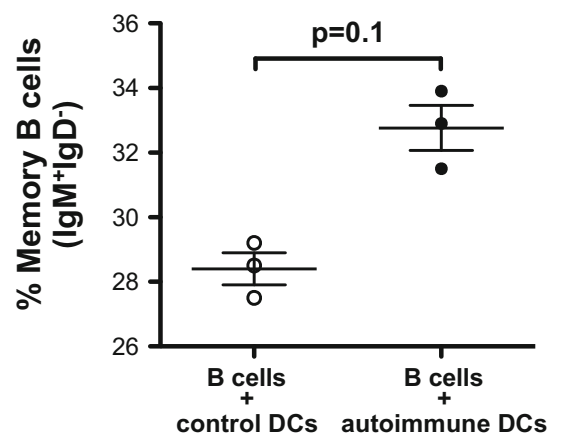

PD-L2

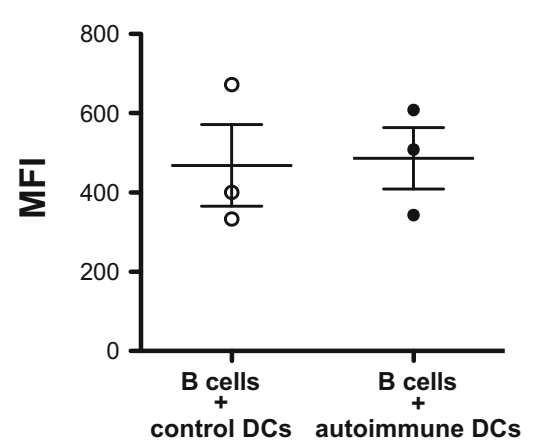

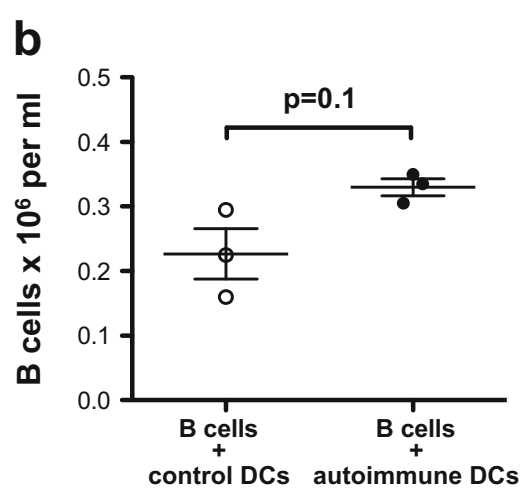

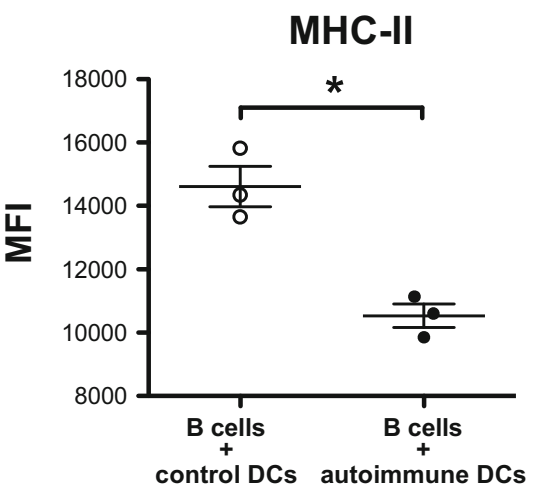

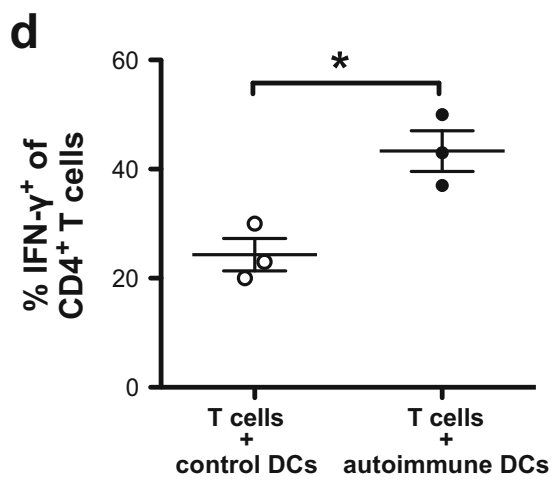

Fig. 6 Autoimmune DCs directly interact with B and T cells to promote their maturation and differentiation in vitro. DCs from aged BWF1 or $[\mathrm{NZW} \times \mathrm{BALB} / \mathrm{c}] \mathrm{F} 1$ control mice were co-cultured with $\mathrm{B}$ or $\mathrm{T}$ cells from young BWF1 mice at a 1:5 or 1:2 ratio, respectively. DC/T cell cocultures were performed in the presence of $1 \mu \mathrm{g} / \mathrm{ml}$ soluble anti-CD3 purified antibody. a Percentage of naïve $\operatorname{IgM}^{+} \operatorname{IgD}{ }^{+}$and memory $\mathrm{IgM}^{+} \mathrm{IgD}^{-} \mathrm{B}$ cells among total B cells obtained after $24 \mathrm{~h}$ of co-culture with control or autoimmune DCs. b Cell count of total B cells
$\left(\mathrm{CD} 19^{+} \mathrm{B} 220^{+} \mathrm{CD} 11 \mathrm{c}^{-}\right)$obtained after 3 days of co-culture with control or autoimmune DCs. c MFI analysis for MHC-II, CD86, and PD-L2 staining within $\mathrm{B}$ cells $\left(\mathrm{CD} 19^{+} \mathrm{B} 220^{+} \mathrm{CD} 11 \mathrm{c}^{-}\right)$obtained after 3 days of co-culture with control or autoimmune DCs. d Percentage of IFN- $\gamma$ producing $\mathrm{T}$ cells (following stimulation with PMA plus ionomycin in the presence of brefeldin A) after 5 days of co-culture with control or autoimmune DCs. The data are presented as the mean \pm S.E.M. $(n=3$ independent experiments); ${ }^{*} p<0.05$ (two-tailed Kruskal-Wallis test) cultured control or autoimmune DCs with purified splenic B cells from young BWF1 mice. After $24 \mathrm{~h}$ of co-culture, we observed that the autoimmune DCs were more efficient at inducing $\mathrm{B}$ cell maturation, as evidenced by a decreased percentage of $\operatorname{IgM}^{+} \operatorname{IgD}^{+}$naïve $B$ cells and an increase in $\operatorname{IgM}^{+} \operatorname{IgD}{ }^{-}$persistent memory B cells (Fig. 6a). Furthermore, although not statistically significant, the autoimmune DCs had a direct positive impact on B cell viability, which was noticeable after 3 days of co-culture (Fig. 6b). On the other hand, after 3 days of co-culture, we also observed a notable decrease in MHC-II expression on B cells activated by autoimmune DCs (Fig. 6c), replicating our observations in vivo (Fig. 2b). 
However, there were no differences in the expression levels of the activation markers CD86 and PD-L2 on B cells after coculture with control or autoimmune DCs (Fig. 6c).

To determine whether autoimmune DCs affect $\mathrm{T}$ cell differentiation directly, we co-cultured autoimmune DCs with purified splenic $\mathrm{CD}^{+} \mathrm{T}$ cells from young BWF1 mice. After 5 days of polyclonal activation in the presence of anti-CD3, the autoimmune DCs were more efficient in differentiating splenic $\mathrm{CD} 4^{+} \mathrm{T}$ cells into IFN- $\gamma$-producing cells compared to control DCs (Fig. 6d). Thus, DCs from an autoimmune context contribute importantly to the hyperproduction of IFN- $\gamma$ by $\mathrm{CD} 4^{+} \mathrm{T}$ cells.

\section{Discussion}

In this study, we demonstrated that the transfer of autoimmune DCs obtained from the spleens of aged BWF1 mice to young healthy BWF1 mice induced a sustained and significant production of autoantibodies compared to the transfer of control DCs. Moreover, when autoimmune DCs were transferred to control mice, we did not see any effect on the production of autoantibodies, indicating that DCs require an appropriate genetic background to activate autoreactive $\mathrm{B}$ cells. The contribution of DCs to the maintenance of immune tolerance has been evaluated by constitutively deleting this population in wild-type mice, triggering spontaneous fatal autoimmunity [4]. In contrast, adoptive transfer of in vitro-maturated bone marrow DCs breaks tolerance and induces the production of autoantibodies as a manifestation of autoimmunity [28]. Overall, these results reveal that DCs play dual roles in immune tolerance, making them key targets for the study of autoimmune diseases. However, the role of DCs in SLE is far from being completely understood.

DCs comprise a heterogeneous immune cell population, where $\mathrm{cDCs}$ and $\mathrm{pDCs}$ represent two of the main subpopulations $[2,12,29]$. Both subsets share antigen-presenting cell characteristics; nevertheless, they show different tissue localizations, phenotypes, and functions. These differences allow them to participate non-redundantly in immune responses and in the mechanisms involved in the maintenance of tolerance, probably impacting the development of lupus. DCs have been implicated in the pathogenesis of lupus based on a correlative link between their copious production of IFN- $\alpha$, a hallmark often seen in human SLE patients and the severity of the disease [30, 31]. A recent study found that $\mathrm{pDC}$ distribution, numbers, and maturation state are increased even before the onset of the disease in lupus-prone mice [32], findings that indicate the potential role of $\mathrm{pDCs}$ in the onset of the disease. However, these alterations differ depending on the lupusprone mouse strains under investigation [33]. Other studies have attempted to determine the specific role of $\mathrm{pDCs}$ in lupus using the transient depletion of pDCs, which resulted in ameliorated autoimmunity [34-36].

Various studies have established the presence of abnormal DCs in lupus pathogenesis, including an aberrant phenotype and altered homeostasis and functionality in both human [13, $14,37,38]$ and murine SLE $[15,17]$. In order to determine the participation of DCs in lupus, these cells have been constitutively deleted in a lupus-prone mouse model, showing that this procedure ameliorates or delays autoimmunity $[4,11]$. In the present study, we detected autoantibodies in the peripheral blood serum as a characteristic symptom of lupus after transferring autoimmune DCs to lupus-prone mice. Autoantibody production induced by the adoptive transfer of in vitromatured bone marrow DCs to normal mice was shown by Georgiev et al., who stated that mature DCs were not able to induce long-lasting autoimmunity or clinical disease expression in normal mice [28]. Here, we did not detect renal damage (evaluated by proteinuria levels) in mice transferred with autoimmune DCs despite high titers of autoantibodies, but we demonstrate several other manifestations of lupus in BWF1 mice.

In agreement with the higher autoantibody titers observed, we found that autoimmune DC transfer induced the expansion of $\mathrm{CD}^{+} \mathrm{B}$ cells or B1-like cells and plasmablasts in the blood of young BWF1 mice. Both lupus patients [21] and aged BWF1 mice [39] have increased $\mathrm{CD}^{+} \mathrm{B}$ cells in their blood, which has been directly correlated with an increase in autoantibodies. Here, we performed a kinetic analysis of $\mathrm{CD}^{+} \mathrm{B}$ cells in the blood of mice that received autoimmune DCs or control DCs, and we found a positive correlation between the appearance of $\mathrm{CD}^{+} \mathrm{B}$ cells and the production of autoantibodies in the serum. In agreement with these results, in the blood serum, we found increased levels of IL-6, a cytokine known to be involved in the proliferation of autoantibodyproducing cells. Autoimmune DC transfer participates in the maturation and activation of splenic $\mathrm{B}$ cells, as evidenced by a decrease in the $\operatorname{IgM}^{+} \operatorname{IgD}^{+}$naïve $\mathrm{B}$ cell population, an increase in the $\operatorname{IgM}^{+} \operatorname{IgD}^{-}$long-lasting memory $\mathrm{B}$ cell population, higher expression of CD86 and PD-L2, and a lower MHC-II expression on B cells. Interestingly, some of these phenomena were also observed in the thymi of these mice, where the presence of $\mathrm{CD}^{+} \mathrm{B}$ cells may be an indication of the activation of autoreactive $\mathrm{T}$ cells [39]. Other studies have already established direct interactions between DCs and B cells in the context of lupus, where DCs from an autoimmune context are capable of increasing B cell effector functions dependent on soluble factors, such as IL-6 and IFN- $\gamma$ [40], and also through direct cell-to-cell contact $[10,41]$. Recently, Menon et al. established a specific role of pDCs on the modulation of autoimmunity, where aberrant pDCs in lupus promote plasmablast differentiation but fail to induce regulatory B cells [42]. On the other hand, cDCs regulate plasmablast responses through $\mathrm{T}$ cell interactions [43]. Our in vitro experiments 
demonstrated that autoimmune DC co-culture with purified B cells replicates most of the characteristics found in B cells of mice treated with autoimmune DCs.

Interestingly, the transfer of autoimmune DCs into young, healthy BWF1 mice induced the expansion of DCs in the blood and spleens, a phenomenon that is characteristic of aged, diseased BWF1 mice [15] and other lupus mouse models [40]. The expansion of DCs requires the presence of different cytokines involved in differentiation, proliferation, and survival. The presence of IL-4 and TNF in the serum of mice 60 days after the transfer of autoimmune DCs could in part contribute to the expansion of DCs. We did not test other cytokines that could be involved in the expansion of particular subsets of DCs. However, the transfer of autoimmune DCs into young BWF1 mice induced increased IFN- $\gamma$-producing $\mathrm{CD} 4^{+} \mathrm{T}$ cells, a phenomenon that was replicated in the in vitro co-culture experiments, indicating that augmented Th1 differentiation was driven by direct interactions with autoimmune DCs. IFN- $\gamma$ is a critical component of the disease in both human $[27,44]$ and murine lupus models $[45,46]$; thus, the direct participation of DCs in this phenomenon makes them interesting targets for future therapies.

Our results support a model where during SLE onset, DCs undergo phenotypic and functional changes, resulting in anomalous immune regulation that impacts $\mathrm{B}$ and $\mathrm{T}$ cell function, contributing to the progression of the disease. Our data demonstrate that $\mathrm{B}$ cells are directly influenced by DCs because naïve B cells decreased and memory B cells increased following treatment with autoimmune DCs. Moreover, we observed an important increase in the percentage of $\mathrm{CD}^{+} \mathrm{B}$ cells in the blood and spleen as a result from the transfer of autoimmune DCs. Interestingly, $\mathrm{CD}^{+} \mathrm{B}$ cells, also called B1like cells, have an increased capacity to produce autoantibodies, although they reside mainly in the peritoneal cavity [39]. Here, we showed that the transfer of autoimmune DCs to lupus-prone mice directly affects B1-like cells; however, we could not determine whether the effect was on the expansion or homing of these cells to the spleen or to the blood. Collectively and based on the potent roles of DCs during the initiation and progression of lupus, we further validate DCs as a potential therapeutic target in autoimmunity. Understanding DC participation in lupus is crucial for the achievement of potential treatments for this disease of unknown etiology.

Author contributions All authors were involved in drafting the article or revising it critically for important intellectual content, and all authors approved the final version to be published.

Study conception and design: NC, DS, CF, MR, MRB. Performed experiments: NC, DS, CF, YH, MJF. Analyzed the data: NC, DS, CF, YH, MJF. Writing the manuscript: NC, DS, MR, MRB

Compliance with ethical standards Animal work was carried out under the institutional regulations of the Fundación Ciencia \& Vida and was approved locally by the ethical review committee of the Facultad de Ciencias, Universidad de Chile.

Funding Funded by FONDECYT 1140431 (MRB), FONDECYT 1121478 (DS), PAI 791100009 (MRB, DS), FONDEQUIP/ EQM114137, and CONICYT PFB-16 (MR).

Conflict of interest The authors declare that they have no conflict of interest.

Open Access This article is distributed under the terms of the Creative Commons Attribution 4.0 International License (http:// creativecommons.org/licenses/by/4.0/), which permits unrestricted use, distribution, and reproduction in any medium, provided you give appropriate credit to the original author(s) and the source, provide a link to the Creative Commons license, and indicate if changes were made.

\section{References}

1. Liao X, Reihl AM, Luo XM. Breakdown of immune tolerance in systemic lupus erythematosus by dendritic cells. J Immunol Res. 2016;2016:6269157, 15 pages. doi:10.1155/2016/6269157.

2. Merad M, Sathe P, Helft J, Miller J, Mortha A. The dendritic cell lineage: ontogeny and function of dendritic cells and their subsets in the steady state and the inflamed setting. Annu Rev Immunol. 2013;31:563-604.

3. Birnberg T, Bar-On L, Sapoznikov A, Caton ML, CervantesBarragán L, Makia D, et al. Lack of conventional dendritic cells is compatible with normal development and T cell homeostasis, but causes myeloid proliferative syndrome. Immunity. 2008;29(6): 986-97.

4. Ohnmacht C, Pullner A, King SB, Drexler I, Meier S, Brocker T, et al. Constitutive ablation of dendritic cells breaks self-tolerance of CD4 T cells and results in spontaneous fatal autoimmunity. J Exp Med. 2009;206(3):549-59.

5. Ioannou M, Alissafi T, Boon L, Boumpas D, Verginis P. In vivo ablation of plasmacytoid dendritic cells inhibits autoimmunity through expansion of myeloid-derived suppressor cells. J Immunol. 2013;190(6):2631-40.

6. Hadeiba H, Lahl K, Edalati A, Oderup C, Habtezion A, Pachynski $\mathrm{R}$, et al. Plasmacytoid dendritic cells transport peripheral antigens to the thymus to promote central tolerance. Immunity. 2012;36(3): $438-50$.

7. Fransen JH, van der Vlag J, Ruben J, Adema GJ, Berden JH, Hilbrands LB. The role of dendritic cells in the pathogenesis of systemic lupus erythematosus. Arthritis Res Ther. 2010;12(207): $1-8$.

8. Seitz HM, Matsushima GK. Dendritic cells in systemic lupus erythematosus. Int Rev Immunol. 2010;29(2):1-21.

9. Dubois B, Bridon JM, Fayette J, Barthélémy C, Banchereau J, Caux $\mathrm{C}$, et al. Dendritic cells directly modulate B cell growth and differentiation. J Leukoc Biol. 1999;66:224-30.

10. Wan S, Zhou Z, Duan B, Morel L. Direct B cell stimulation by dendritic cells in a mouse model of lupus. Arthritis Rheumatol. 2008;58(6):1741-50.

11. Teichmann LL, Ols ML, Kashgarian M, Reizis B, Kaplan DH, Shlomchik MJ. Dendritic cells in lupus are not required for activation of T and B cells but promote their expansion, resulting in tissue damage. Immunity. 2010;33(6):967-78.

12. Coutant F, Miossec P. Altered dendritic cell functions in autoimmune disease: distinct and overlapping profiles. Nat Rev Rheumatol. 2016;12(12):703-15. 
13. Klarquist J, Zhou Z, Shen N, Janssen EM. Dendritic cells in systemic lupus erythematosus: from pathogenic players to therapeutic tools. Mediat Inflamm. 2016;2016:5045248, 12 pages. doi:10. 1155/2016/5045248.

14. Jin O, Kavikondala S, Mok MY, Sun L, Gu J, Fu R, et al. Abnormalities in circulating plasmacytoid dendritic cells in patients with systemic lupus erythematosus. Arthritis Res Ther. 2010;12(4): R137.

15. Gleisner MA, Reyes P, Alfaro J, Solanes P, Simon V, Crisostomo N, et al. Dendritic and stromal cells from the spleen of lupic mice present phenotypic and functional abnormalities. Mol Immunol. 2013;54(3-4):423-34.

16. Perry D, Sang A, Yin Y, Zheng Y, Morel L. Murine models of systemic lupus erythematosus. J Biomed Biotechnol. 2011;2011: 271694, 19 pages. doi:10.1155/2011/271694.

17. Colonna L, Dinnall J, Shivers DK, Frisoni L, Caricchio R, Gallucci S. Abnormal costimulatory phenotype and function of dendritic cells before and after the onset of severe murine lupus. Arthritis Res Ther. 2006;8(2):1-11.

18. Pape KA, Taylor JJ, Maul RW, Gearhart PJ, Jenkins MK. Different $B$ cell populations mediate early and late memory during an andogenous immune response. Science. 2011;331(6021):1203-7.

19. William MJ, Euler C, Christensen S, Shlomchik MJ. Evolution of autoantibody responses via somatic hypermutation outside of germinal centers. Science. 2002;297(5589):2066-70.

20. Hoyer BF, Moser K, Hauser AE, Peddinghaus A, Voigt C, Eilat D, et al. Short-lived plasmablasts and long-lived plasma cells contribute to chronic humoral autoimmunity in NZB/W mice. J Exp Med. 2004;199(11):1577-84.

21. Böhm I. Increased peripheral blood B-cells expressing the CD5 molecules in association to autoantibodies in patients with lupus erythematosus and evidence to selectively down-modulate them. Biomed Pharmacother. 2004;58:338-43.

22. Dean G, Tyrrell-Price J, Crawley E, Isenberg D. Cytokines and systemic lupus erythematosus. Ann Rheum Dis. 2000;59:243-51.

23. Yang M, Rui K, Wang S, Lu L. Regulatory B cells in autoimmune diseases. Cell Mol Immunol. 2013;10(2):122-32.

24. Matsushita T, Horikawa M, Iwata Y, Tedder TF. Regulatory B cells (B10 cells) and regulatory $\mathrm{T}$ cells have independent roles in controlling experimental autoimmune encephalomyelitis initiation and late-phase immunopathogenesis. J Immunol. 2010;185:2240-52.

25. Andrews BS, Eisenberg RA, Theofilopoulos AN, Izui S, Wilson $\mathrm{CB}$, McConahey PJ, et al. Spontaneous murine lupus-like syndromes. J Exp Med. 1978;148:1198-215.

26. Lim MS, Straus SE, Dale JK, Fleisher TA, Stetler-Stevenson M, Strober W, et al. Pathological findings in human autoimmune lymphoproliferative syndrome. Am J Pathol. 1998;153(5):1541-50.

27. Csiszár A, Nagy G, Gergely P, Pozsonyi T, Pócsik E. Increased interferon-gamma (IFN-gamma), IL-10 and decreased IL-4 mRNA expression in peripheral blood mononuclear cells (PBMC) from patients with systemic lupus erythematosus (SLE). Clin Exp Immunol. 2000;122(3):464-70.

28. Georgiev M, Agle LM, Chu JL, Elkon KB, Ashany D. Mature dendritic cells readily break tolerance in normal mice but do not lead to disease expression. Arthritis Rheum. 2005;52(1):225-38.

29. Steinman RM, Idoyaga J. Features of the dendritic cell lineage. Immunol Rev. 2010;234(1):5-17.
30. Rönnblom L, Pascual V. The innate immune system in SLE: type I interferons and dendritic cells. Lupus. 2008;17:394-9.

31. Kim JM, Park SH, Kim HY, Kwok SK. A plasmacytoid dendritic cells-type I interferon axis is critically implicated in the pathogenesis of systemic lupus erythematosus. Int J Mol Sci. 2015;16(6): $14158-70$

32. Scott JL, Wirth JR, EuDaly JG, Gilkeson GS, Cunningham MA. Plasmacytoid dendritic cell distribution and maturation are altered in lupus prone mice prior to the onset of clinical disease. Clin Immunol. 2016;175:109-14.

33. Zhou Z, Ma J, Xiao C, Han X, Qiu R, Wang Y, et al. Phenotypic and functional alterations of pDCs in lupus-prone mice. Sci Rep. 2016;6:20373, 11 pages. doi:10.1038/srep20373.

34. Rowland SL, Riggs JM, Gilfillan S, Bugatti M, Vermi W, Kolbeck $\mathrm{R}$, et al. Early, transient depletion of plasmacytoid dendritic cells ameliorates autoimmunity in a lupus model. J Exp Med. 2014;211(10):1977-91.

35. Cao W. Pivotal functions of plasmacytoid dendritic cells in systemic autoimmune pathogenesis. J Clin Immunol. 2014;5(2):212.

36. Zhan Y, Carrington EM, Ko HJ, Vikstrom IB, Oon S, Zhang JG, et al. Bcl 2 antagonists kill plasmacytoid dendritic cells from lupusprone mice and dampen interferon $\alpha$ production. Arthritis Rheum. 2015;67(3):797-808.

37. Köller M, Zwölfer B, Steiner G, Smolen JS, Scheinecker C. Phenotypic and functional deficiencies of monocyte-derived dendritic cells in systemic lupus erythematosus (SLE) patients. Int Immunol. 2004;16(11):1595-604.

38. Ding D, Mehta H, McCune WJ, Kaplan MJ. Aberrant phenotype and function of myeloid dendritic cells in systemic lupus erythematosus. J Immunol. 2006;177(9):5878-89.

39. Ishikawa $\mathrm{S}$, Matsushima $\mathrm{K}$. Aberrant $\mathrm{B} 1$ cell trafficking in a murine model for lupus. Front Biosci. 2007;12:790-1803.

40. Sang A, Zheng YY, Yin Y, Dozmorov I, Li H, Hsu HC, et al. Dysregulated cytokine production by dendritic cells modulates B cell responses in the NZM2410 mouse model of lupus. PLoS One. 2014;9(8):e102151. doi:10.1371/journal.pone.0102151.

41. Ding C, Cai Y, Marroquin J, Ildstad ST, Yan J. Plasmacytoid dendritic cells regulate autoreactive $B$ cell activation via soluble factors and in a cell-to-cell contact manner. J Immunol. 2009;183(11): 7140-9.

42. Menon M, Blair PA, Isenberg DA, Mauri C. A regulatory feedback between plasmacytoid dendritic cells and regulatory $\mathrm{B}$ cells is aberrant in systemic lupus erythematosus. Immunity. 2016;44(3): 683-97.

43. Ols ML, Cullen JL, Turqueti-Neves A, Giles J, Shlomchik MJ. Dendritic cells regulate extrafollicular autoreactive B cells via $\mathrm{T}$ cells expressing Fas and Fas ligand. Immunity. 2016;45(5):105265 .

44. Koenig KF, Groeschl I, Pesickova SS, Tesar V, Eisenberger U, Trendelenburg M. Serum cytokine profile in patients with active lupus nephritis. Cytokine. 2012;60(2):410-6.

45. Balomenos $\mathrm{D}$, Rumold $\mathrm{R}$, Theofilopoulos $\mathrm{AN}$. Interferon-gamma is required for lupus-like disease and lymphoaccumulation in MRLlpr mice. J Clin Invest. 1998;101(2):364-71.

46. Theofilopoulos AN, Lawson BR. Tumour necrosis factor and other cytokines in murine lupus. Ann Rheum Dis. 1999;58(Suppl I):I4955 . 